\title{
Biogenic Orthorhombic $\alpha$-Calcium Formate from Sediments of Alkali Lake, Oregon, USA
}

\author{
Nikita V. Chukanov ${ }^{1,2}$, Cesar Menor-Salvan ${ }^{3} \mathbb{C}$, Vladislav V. Gurzhiy $4, * \mathbb{C}$, Alina R. Izatulina ${ }^{4}$, Igor V. Pekov ${ }^{2,5}$, \\ Marina F. Vigasina ${ }^{2}\left(\mathbb{D}\right.$, Dmitry A. Ksenofontov ${ }^{2}$ and Sergey N. Britvin ${ }^{4}(\mathbb{D})$ \\ 1 Institute of Problems of Chemical Physics, Russian Academy of Sciences, Chernogolovka, \\ 142432 Moscow, Russia; chukanov@icp.ac.ru \\ 2 Faculty of Geology, Moscow State University, Vorobievy Gory, 119991 Moscow, Russia; \\ igorpekov@mail.ru (I.V.P.); vigasina55@mail.ru (M.F.V.); ksen53@gmail.com (D.A.K.) \\ 3 Departamento de Biología de Sistemas/IQAR, Universidad de Alcalá, 28805 Madrid, Spain; \\ cesar.menor@uah.es \\ 4 Crystallography Department, Institute of Earth Sciences, Saint-Petersburg State University, \\ 199034 Saint-Petersburg, Russia; alina.izatulina@mail.ru (A.R.I.); sbritvin@gmail.com (S.N.B.) \\ 5 Vernadsky Institute of Geochemistry and Analytical Chemistry, Russian Academy of Sciences, \\ 119991 Moscow, Russia \\ * Correspondence: vladgeo17@mail.ru or vladislav.gurzhiy@spbu.ru
}

check for

updates

Citation: Chukanov, N.V.;

Menor-Salvan, C.; Gurzhiy, V.V.;

Izatulina, A.R.; Pekov, I.V.; Vigasina,

M.F.; Ksenofontov, D.A.; Britvin, S.N.

Biogenic Orthorhombic $\alpha$-Calcium

Formate from Sediments of Alkali

Lake, Oregon, USA. Minerals 2021, 11

448. https://doi.org/10.3390/

$\min 11050448$

Academic Editor: Sytle M. Antao

Received: 3 April 2021

Accepted: 20 April 2021

Published: 23 April 2021

Publisher's Note: MDPI stays neutral with regard to jurisdictional claims in published maps and institutional affiliations.

Copyright: (c) 2021 by the authors. Licensee MDPI, Basel, Switzerland. This article is an open access article distributed under the terms and conditions of the Creative Commons Attribution (CC BY) license (https:/ / creativecommons.org/licenses/by/ $4.0 /)$.
Abstract: Centimeter-sized crystals of orthorhombic calcium formate, $\alpha-\mathrm{Ca}\left(\mathrm{HCO}_{2}\right)_{2}$ from Alkali Lake, Oregon, USA have been studied by means of powder and single-crystal X-ray diffraction analysis, infrared, and Raman spectroscopy. Based on the data on carbon isotope abundance in calcium formate and associated minerals, it was concluded that the formation of $\alpha-\mathrm{Ca}\left(\mathrm{HCO}_{2}\right)_{2}$ may be a result of a combination of two factors: lake microbial metabolism and anthropogenic pollution with Agent Orange. Possible causes of stability of the low-density tetragonal $\beta-\mathrm{Ca}\left(\mathrm{HCO}_{2}\right)_{2}$ polymorph (formicaite) in boron ores are discussed.

Keywords: calcium formate; mineral; formicaite; polymorphism; crystal structure; IR spectroscopy; Raman spectroscopy; bacterial formate production; sedimentary deposits; alkali lake; Oregon; Agent Orange

\section{Introduction}

Crystalline formates are rare in nature. There are only two species belonging to this class of minerals: formicaite $\mathrm{Ca}\left(\mathrm{HCO}_{2}\right)_{2}$ [1] and dashkovaite $\mathrm{Mg}\left(\mathrm{HCO}_{2}\right)_{2} \cdot 2 \mathrm{H}_{2} \mathrm{O}$ [2]. Both formate minerals were discovered in Russia. They were found in low-temperature hydrothermal veinlets in three boron-rich skarn deposits, namely Solongo, Buryatia, Siberia, Novofrolovskoe, Northern Urals (formicaite), and Korshunovskoe, the Irkutsk district, Siberia (dashkovaite). Later, trace amounts of these minerals have been detected by us in boron-bearing metasomatic parageneses of some other deposits by means of IR spectroscopy which was found to be an effective tool to detect small amounts of the formate minerals. Using this method, we also detected admixtures of unidentified formates in sediments of saline lakes of California, USA. Thus, the confinement of formates to areas bearing boron mineralization is a reliably established fact.

There are four polymorphic modifications $(\alpha-\delta)$ of synthetic anhydrous calcium formate known nowadays (Table 1) [3,4]. Orthorhombic $\alpha$ - and tetragonal $\beta-\mathrm{Ca}\left(\mathrm{HCO}_{2}\right)_{2}$ can persist at ambient conditions, while $\gamma$ - and $\delta$-modifications are transition phases and can exist in a high-temperature range of $150-300{ }^{\circ} \mathrm{C}$ [4]. Besides, both $\alpha$ - and $\beta$ modifications transform directly to $\gamma$ - and then to $\delta$-modification upon heating $(\alpha \rightarrow \gamma \rightarrow$ $\delta$ and $\beta \rightarrow \gamma \rightarrow \delta$ ), and there is no $\alpha \rightarrow \beta$ transformation detected to date, while a series of phase transitions at cooling include all modifications: $\delta \rightarrow \gamma \rightarrow \beta \rightarrow \alpha$. Among them, $\alpha-\mathrm{Ca}\left(\mathrm{HCO}_{2}\right)_{2}$ is supposed to be the most stable, since the $\beta$-modification easily transforms to the orthorhombic $\alpha$-modification at room temperature in a humid atmosphere [5]. It 
should be noted that the crystal structure of $\gamma-\mathrm{Ca}\left(\mathrm{HCO}_{2}\right)_{2}$ is still not determined, and indexation of its powder pattern in a monoclinic unit cell leaves some doubts due to the rather rare tendency of symmetry reduction with heating.

Table 1. Crystallographic data for $\mathrm{Ca}\left(\mathrm{HCO}_{2}\right)_{2}$ polymorphic modifications.

\begin{tabular}{|c|c|c|c|c|c|c|}
\hline Modification & Sp. Gr.* & $a, \AA / \alpha,{ }^{\circ}$ & $b, \AA / \beta, \circ$ & $c, \AA / \gamma,{ }^{\circ}$ & $V, \AA^{3} / \rho, \mathrm{g} / \mathrm{cm}^{3}$ & Reference \\
\hline$\alpha$ & $\mathrm{Pbca}$ & $\begin{array}{c}10.229(1) \\
10.163- \\
10.228(3)\end{array}$ & $\begin{array}{l}6.256(1) \\
6.261(3)- \\
6.288(1)\end{array}$ & $\begin{array}{l}13.243(1) \\
13.238(5)- \\
13.407(2)\end{array}$ & $\begin{array}{c}847.47(2) / 2.040 \\
847.73-858.81 / 2.008- \\
2.038\end{array}$ & $\begin{array}{c}\text { This work } \\
\text { [6-10] }\end{array}$ \\
\hline $\begin{array}{c}\beta \text { (synt) } \\
\beta \text { (Formicaite) }\end{array}$ & $P 4_{1} 2_{1} 2$ & $\begin{array}{c}6.776(2) \\
6.77(1)\end{array}$ & $\begin{array}{c}6.776(2) \\
6.77(1)\end{array}$ & $\begin{array}{c}9.453(5) \\
9.46(1)\end{array}$ & $\begin{array}{l}434.03 / 1.991 \\
434(1) / 1.990\end{array}$ & $\begin{array}{l}{[5]} \\
{[1]}\end{array}$ \\
\hline$\gamma$ & $P 2, P m$ or $P 2 / m$ & $6.75 / 90$ & $6.705 / 119.47$ & $5.78 / 90$ & $227.75 / 1.897$ & {$[4]$} \\
\hline$\delta$ & $I 4_{1} /$ amd & $6.75(1)$ & $6.75(1)$ & $10.04(2)$ & $457.45 / 1.889$ & [5] \\
\hline
\end{tabular}

${ }^{*}$ Crystallographic data for $\alpha-\mathrm{Ca}\left(\mathrm{HCO}_{2}\right)_{2}$ are given in a uniform setting. However, various settings of the same unit cell and isomorphic space groups (Pbca or Pcab) can be found in original works.

Formicaite, the tetragonal $\beta$-modification of $\mathrm{Ca}\left(\mathrm{HCO}_{2}\right)_{2}$, was the first natural salt of formic acid approved by the International Mineralogical Association as a mineral species. The orthorhombic calcium formate polymorph, $\alpha-\mathrm{Ca}\left(\mathrm{HCO}_{2}\right)_{2}$, is known as a synthetic phase, which among the other pathways, can be obtained by evaporation of a calcite solution in formic acid [11].

In this paper, we describe orthorhombic calcium formate from sediments of highly saline, and alkaline Alkali Lake, Oregon, USA. Orthorhombic $\alpha-\mathrm{Ca}\left(\mathrm{HCO}_{2}\right)_{2}$ occurs there as aggregates of colorless, flattened crystals up to $5 \mathrm{~mm}$ across (Figure 1).

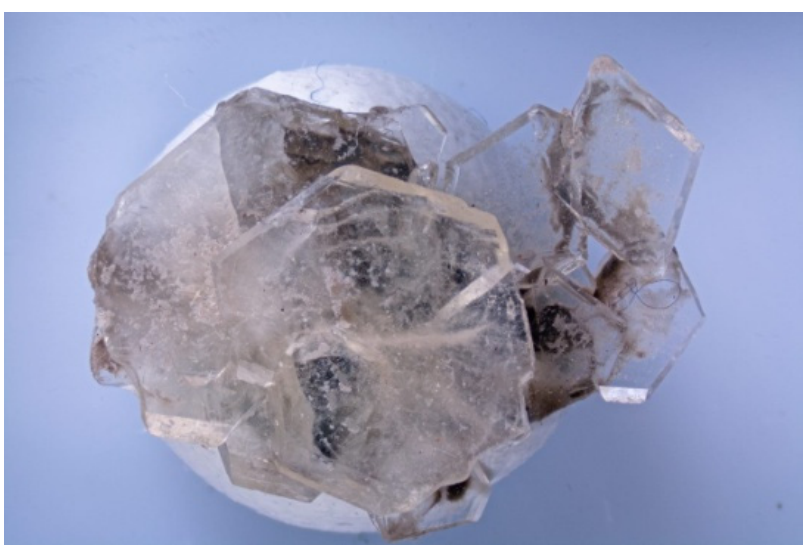

(a)

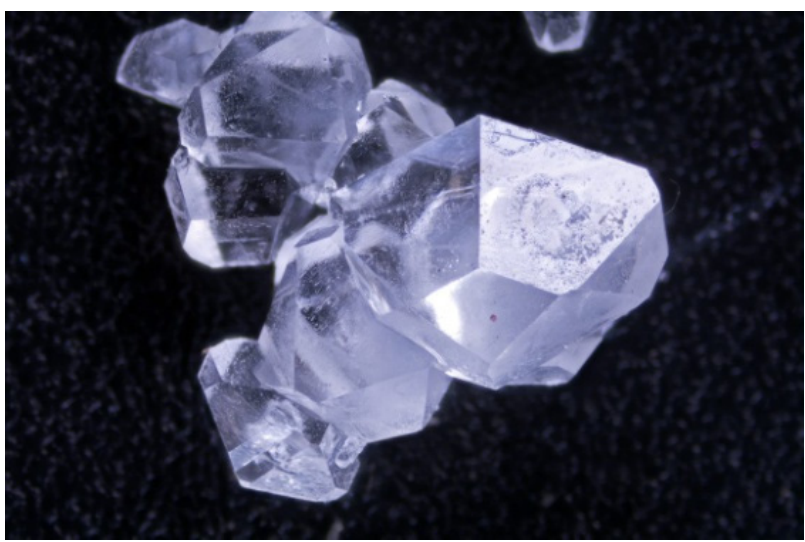

(b)

Figure 1. Crystals of orthorhombic $\alpha-\mathrm{Ca}\left(\mathrm{HCO}_{2}\right)_{2}$ from Alkali Lake: (a) and synthetic orthorhombic Ca formate obtained in Alkali Lake simulation; (b) Field of view width $15 \mathrm{~mm}$ (a) and $6 \mathrm{~mm}$ (b).

\section{Materials and Methods}

Centimeter-sized crystals (Figure 1a) of orthorhombic $\alpha-\mathrm{Ca}\left(\mathrm{HCO}_{2}\right)_{2}$ were obtained from the lacustrine sediments of Alkali Lake, Valley Falls, Lake Co., Lake County, OR, USA.

In order to obtain IR absorption spectra, powder samples of orthorhombic $\alpha-\mathrm{Ca}$ formate and formicaite (used for comparison) were mixed with anhydrous $\mathrm{KBr}$, pelletized, and analyzed using an ALPHA FTIR spectrometer (Bruker Optics; Ettlingen, Germany) at a resolution of $4 \mathrm{~cm}^{-1}$. A total of 16 scans were collected. The IR spectrum of an analogous pellet of pure $\mathrm{KBr}$ was used as a reference.

Raman spectra were obtained on randomly oriented samples using an EnSpectr R532 (EnSpectr, Chernogolovka, Russia) instrument (calibrated using the $520 \mathrm{~cm}^{-1}$ band of Si) 
with a green laser (the exciting wavelength $\lambda=532 \mathrm{~nm}$ ) at room temperature. The output power of the laser beam was about $14 \mathrm{~mW}$. The spectrum was processed using the EnSpectr expert mode program in the range from 100 to $4000 \mathrm{~cm}^{-1}$ with the use of a holographic diffraction grating with 1800 lines $/ \mathrm{cm}$; a resolution was about $6 \mathrm{~cm}^{-1}$. The diameter of the focal spot on the sample was about 10-12 $\mu \mathrm{m}$. The backscattered Raman signal was collected with a $40 \times$ objective the signal acquisition time for a single scan of the spectral range was $1 \mathrm{~s}$ and the signals were averaged over 100 scans for orthorhombic Ca-formate and over 50 scans for formicaite.

Powder X-ray diffraction (PXRD) data were collected with a STOE Stadi MP (STOE, Darmstadt, Germany) powder diffractometer operated with monochromated (curved Ge(111)) $\operatorname{CoK} \alpha_{1}$ radiation $\left(\lambda\left(\mathrm{CoK} \alpha_{1}\right)=1.78896 \AA\right)$ at $45 \mathrm{kV}$ and $35 \mathrm{~mA}$ using transmission geometry with a scan step of $0.02^{\circ}$. PXRD data was processed using STOE WinXPOW software [12].

Single crystal X-ray diffraction (SCXRD) studies were carried out at $100 \mathrm{~K}$ using a Rigaku Oxford Diffraction XtaLab SuperNova diffractometer (Rigaku Oxford Diffraction, Oxford, UK) equipped with a hybrid photon counting HyPix-3000 detector operated with monochromated, microfocused $\mathrm{CuK} \alpha$ radiation $(\lambda(\mathrm{CuK} \alpha)=1.54184 \AA)$ at $50 \mathrm{kV}$ and $0.8 \mathrm{~mA}$. Data were integrated and corrected for background, Lorentz, and polarization effects. An empirical absorption correction based on spherical harmonics implemented in the SCALE3 ABSPACK algorithm was applied in the CrysAlisPro program [13]. The unit-cell parameters (Table 2) were refined using the least-squares techniques. The structure was solved by a dualspace algorithm and refined using the SHELX programs $[14,15]$ incorporated in the OLEX2 program package [16]. The final model included coordinates and anisotropic displacement parameters for all non-H atoms (Table 3). The carbon-bound $\mathrm{H}$ atoms were localized from different Fourier maps and were included in the refinement without any restraints with individual isotropic displacement parameters. Supplementary crystallographic data were deposited in the Inorganic Crystal Structure Database (ICSD) and can be obtained by quoting the CSD 2070226 via www.ccdc.cam.ac.uk/structures/ (see Supplementary Materials).

Table 2. Crystallographic data for $\alpha-\mathrm{Ca}\left(\mathrm{HCO}_{2}\right)_{2}$ from Alkali Lake.

\begin{tabular}{|c|c|}
\hline Crystal System & Orthorhombic \\
\hline Space group & $\mathrm{Pbca}$ \\
\hline$a(\AA)$ & $10.22943(12)$ \\
\hline$b(\AA)$ & $6.25587(9)$ \\
\hline$c(\AA)$ & $13.24297(18)$ \\
\hline$V\left(\AA^{3}\right)$ & $847.471(19)$ \\
\hline Molecular weight & 130.12 \\
\hline$\mu\left(\mathrm{mm}^{-1}\right)$ & 11.986 \\
\hline Temperature (K) & $100(2)$ \\
\hline Z & 8 \\
\hline$D_{\text {calc }}\left(\mathrm{g} / \mathrm{cm}^{3}\right)$ & 2.040 \\
\hline Crystal size $\left(\mathrm{mm}^{3}\right)$ & $0.16 \times 0.11 \times 0.08$ \\
\hline Radiation & $\mathrm{CuK \alpha}$ \\
\hline Total reflections & 6597 \\
\hline Unique reflections & 806 \\
\hline Angle range $2 \theta\left(^{\circ}\right)$ & $13.37-140.00$ \\
\hline Reflections with $\left|F_{\mathrm{o}}\right| \geq 4 \sigma_{F}$ & 802 \\
\hline$R_{\text {int }}$ & 0.0461 \\
\hline$R_{\sigma}$ & 0.0188 \\
\hline$R_{1}\left(\left|F_{0}\right|>4 \sigma_{F}\right)$ & 0.0195 \\
\hline$w R_{2}\left(\left|F_{\mathrm{O}}\right| \geq 4 \sigma_{F}\right)$ & 0.0542 \\
\hline$R_{1}$ (all data) & 0.0195 \\
\hline$w R_{2}$ (all data) & 0.0542 \\
\hline$S$ & 1.090 \\
\hline$\rho_{\min }, \rho_{\max }, e / \AA^{3}$ & $-0.296,0.408$ \\
\hline CSD & 2070226 \\
\hline
\end{tabular}


Table 3. Atomic coordinates and isotropic displacement parameters $\left(\AA^{2}\right)$ for $\alpha-\mathrm{Ca}\left(\mathrm{HCO}_{2}\right)_{2}$ from Alkali Lake.

\begin{tabular}{ccccc}
\hline Atom & $\boldsymbol{x}$ & $\boldsymbol{y}$ & $\boldsymbol{z}$ & $\boldsymbol{U}_{\mathrm{eq}}$ \\
\hline Ca1 & $0.63497(2)$ & $0.46904(4)$ & $0.60687(2)$ & $0.00687(15)$ \\
O1 & $0.47731(8)$ & $0.28344(15)$ & $0.70119(7)$ & $0.0118(2)$ \\
O2 & $0.29850(8)$ & $0.28148(15)$ & $0.79756(7)$ & $0.0104(2)$ \\
O3 & $0.79847(8)$ & $0.63126(15)$ & $0.51242(7)$ & $0.0131(2)$ \\
O4 & $0.96604(8)$ & $0.80824(15)$ & $0.45160(7)$ & $0.0125(2)$ \\
C1 & $0.37446(11)$ & $0.3653(2)$ & $0.73323(10)$ & $0.0091(3)$ \\
H1 & $0.3486(15)$ & $0.503(3)$ & $0.7099(14)$ & $0.014(4)$ \\
C2 & $0.88857(12)$ & $0.6535(2)$ & $0.44933(10)$ & $0.0102(3)$ \\
H2 & $0.9009(18)$ & $0.547(3)$ & $0.3972(12)$ & $0.012(4)$ \\
\hline
\end{tabular}

\section{Results}

\subsection{Infrared Absorption Spectroscopy}

The bands of fundamental modes in the IR spectra of orthorhombic $\alpha$-Ca formate and formicaite (Figure 2) were observed in the following ranges: $2870-2900 \mathrm{~cm}^{-1}(\mathrm{C}-\mathrm{H}$ stretching vibrations); $1580-1660 \mathrm{~cm}^{-1}$ (antisymmetric stretching vibrations of the $-\mathrm{CO}_{2}$ carboxylate group); $1350-1400 \mathrm{~cm}^{-1}$ (symmetric stretching vibrations of the $-\mathrm{CO}_{2}$ group combined with $\mathrm{O}-\mathrm{C}-\mathrm{H}$ bending vibrations); and $780-810 \mathrm{~cm}^{-1}$ (bending vibrations of the $-\mathrm{CO}_{2}$ group combined with $\mathrm{O}-\mathrm{C}-\mathrm{H}$ bending vibrations). Weak bands in the ranges 2690 2780 and $2940-3010 \mathrm{~cm}^{-1}$ corresponded to overtones and combination modes, respectively.

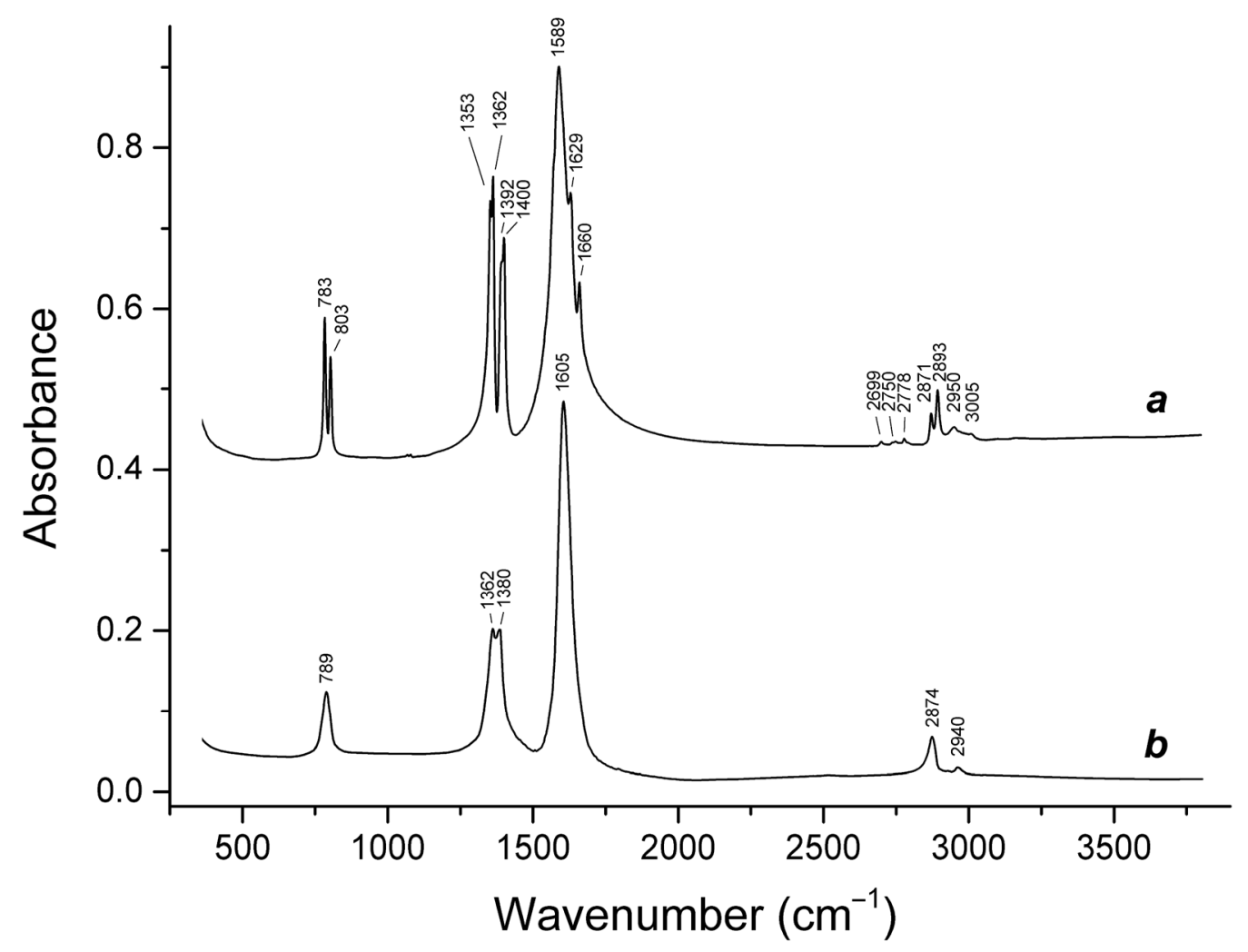

Figure 2. Powder infrared absorption spectra of: (a) orthorhombic $\alpha$-Ca formate from Alkali Lake and; (b) formicaite holotype sample [1]. The spectra have been offset for comparison.

The presence of single bands at 789,1605 , and $2874 \mathrm{~cm}^{-1}$ in the IR spectrum of formicaite was in agreement with the presence of the only type of the formate anions in the crystal structure of $\alpha-\mathrm{Ca}\left(\mathrm{HCO}_{2}\right)_{2}$. The doublet $1362+1380 \mathrm{~cm}^{-1}$ was related to the 
mixed modes involving in-plane and out-of-plane $\mathrm{O}-\mathrm{C}-\mathrm{H}$ bending vibrations combined with symmetric stretching vibrations of the carboxylate group.

In the IR spectrum of orthorhombic $\alpha$-Ca formate, each fundamental band was split into two components which reflected the presence of two nonequivalent formate anions in the crystal structure of $\alpha-\mathrm{Ca}\left(\mathrm{HCO}_{2}\right)_{2}$ (Section 3.3). Additional splitting of the band of antisymmetric stretching vibrations of the carboxylate group may be due to Fermi resonance with an overtone of the combined $\mathrm{O}-\mathrm{C}-\mathrm{H}$ and $\mathrm{O}-\mathrm{C}-\mathrm{O}$ bending vibrations.

\subsection{Raman Spectroscopy}

The Raman spectra of $\alpha$ - and $\beta$-modifications of $\mathrm{Ca}\left(\mathrm{HCO}_{2}\right)_{2}$ are presented in Figure 3 . The assignment of the Raman bands is as follows $[17,18]$ :

- 2870 to $2890 \mathrm{~cm}^{-1}, \mathrm{C}-\mathrm{H}$ stretching vibrations;

- $\quad 1573$ to $1600 \mathrm{~cm}^{-1}$, antisymmetric stretching vibrations of the $-\mathrm{CO}_{2}$ group;

- 1353 to $1387 \mathrm{~cm}^{-1}$, symmetric stretching vibrations of the $-\mathrm{CO}_{2}$ group;

- $1069 \mathrm{~cm}^{-1}$, in-plane $\mathrm{H}-\mathrm{C}-\mathrm{O}$ bending mode;

- 754 to $800 \mathrm{~cm}^{-1}$, bending vibrations of the $-\mathrm{CO}_{2}$ group combined with $\mathrm{O}-\mathrm{C}-\mathrm{H}$ bending vibrations;

- 213 and $233 \mathrm{~cm}^{-1}$, stretching vibrations involving Ca $\cdots \mathrm{O}$ ionic bonds.

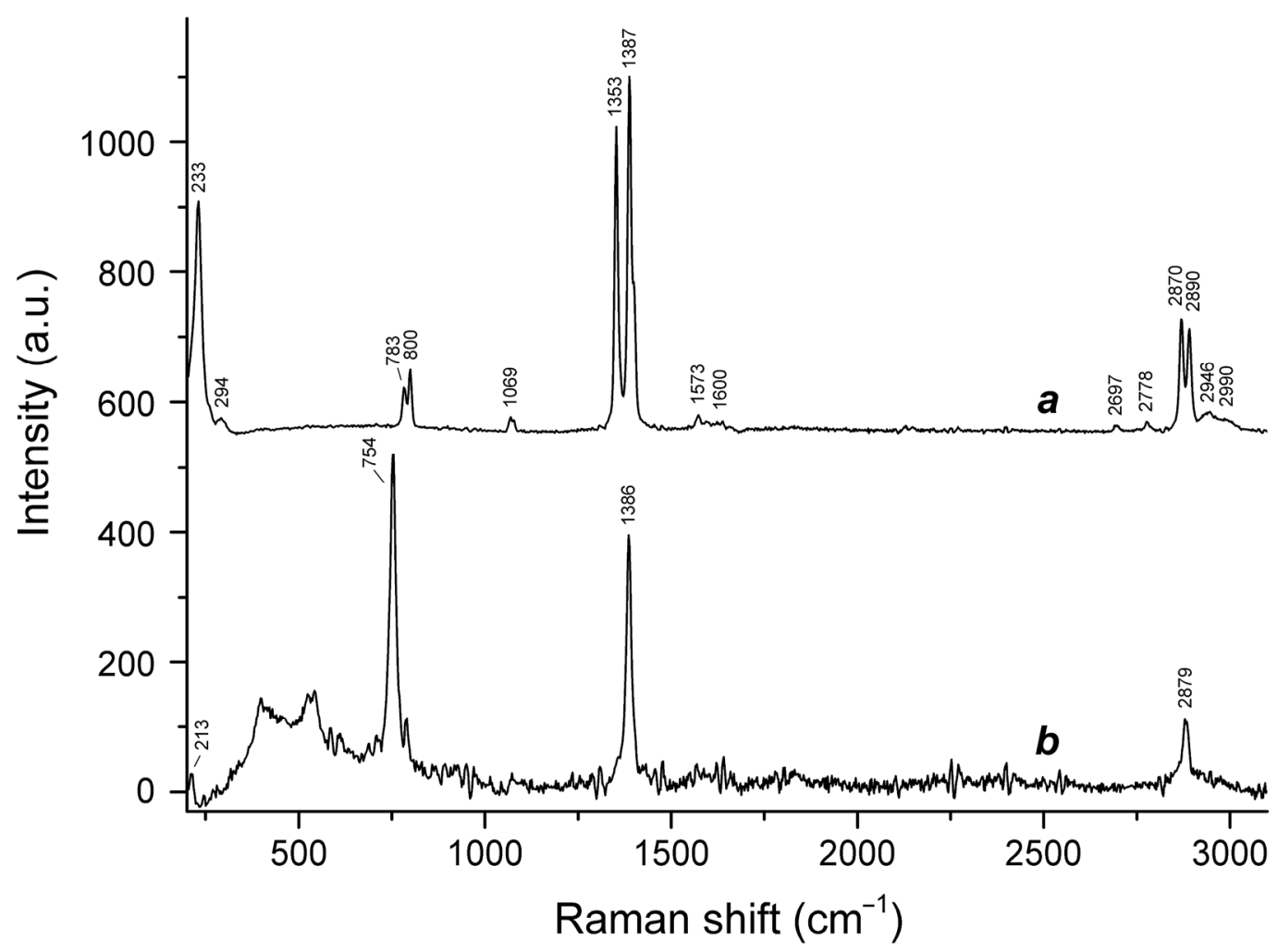

Figure 3. Raman spectra of: (a) orthorhombic calcium formate from Alkali Lake and; (b) formicaite holotype sample. The spectra have been offset for comparison.

The bands in the range of $390-550 \mathrm{~cm}^{-1}$ observed in the Raman spectrum of formicaite were due to unidentified impurities. Other weak bands in the Raman spectra of $\alpha$ - and $\beta-\mathrm{Ca}\left(\mathrm{HCO}_{2}\right)_{2}$ corresponded to overtones and combination modes.

The band of $\mathrm{Ca} \cdots \mathrm{O}$ stretching vibrations in the Raman spectrum of $\alpha-\mathrm{Ca}\left(\mathrm{HCO}_{2}\right)_{2}$ (at $233 \mathrm{~cm}^{-1}$ ) shifted towards higher frequencies as compared to the analogous band of $\beta-\mathrm{Ca}\left(\mathrm{HCO}_{2}\right)_{2}$ observed at $213 \mathrm{~cm}^{-1}$. This phenomenon is related to the differences in the 
coordination of $\mathrm{Ca}$ in the structures of these polymorphs, the coordination numbers of $\mathrm{Ca}$ being equal to 7 in $\alpha-\mathrm{Ca}\left(\mathrm{HCO}_{2}\right)_{2}$ and 8 in $\beta-\mathrm{Ca}\left(\mathrm{HCO}_{2}\right)_{2}$.

\subsection{X-ray Diffraction Data and Crystal Structure}

The crystal structure of $\alpha$-Ca formate was first described in the late 1940s [6]. Then, it was re-determined several times in the 1970s and 1980s [7-10] in various settings of the same orthorhombic unit cell (Table 1) and isomorphic space groups (Pbca or Pcab). The most recent refinement preceding our work was reported by Wang et al. [19].

There was one crystallographically non-equivalent $\mathrm{Ca}$ atom in the structure of $\alpha$ $\mathrm{Ca}(\mathrm{HCOO})_{2}$ which was coordinated by seven $\mathrm{O}$ atoms of two unique formate groups (Figure 4a) to form a distorted pentagonal bipyramid as a coordination polyhedron. Six formate groups were involved in the coordination; only one of them was bidentate, acting as a chelate ligand, while the other five groups were linked to the $\mathrm{Ca}$ atom in a monodentate manner. Ca-centered polyhedra shared edges with the adjacent distorted bipyramids to form dioctahedral-like layers (Figure $4 \mathrm{~b}$ ) that were arranged parallel to (001) and were linked in a framework structure via bridging formate groups (Figure 4c). It should be noted that in some of the previous works, coordination of Ca-centered polyhedra was described as an 8 - or $(7+1)$-fold with one long contact Ca1 $\cdots \mathrm{O} 1=3.413(1) \AA$. However, this contact is

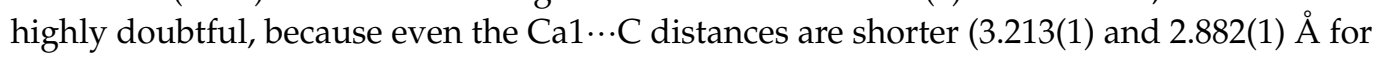
$\mathrm{C} 1$ and $\mathrm{C} 2$, respectively), and the 7-fold geometry satisfies bond-valence sums (Table 4).

Table 4. Selected bond lengths $(\AA)$, angles $\left({ }^{\circ}\right)$, and bond-valence sums (BVS, in valence units (v.u.)) in the crystal structure of $\alpha-\mathrm{Ca}\left(\mathrm{HCO}_{2}\right)_{2}$ from Alkali Lake.

\begin{tabular}{|c|c|c|c|c|}
\hline \multicolumn{2}{|c|}{ Bond * } & \multirow{2}{*}{$\begin{array}{c}\text { BVS } \\
0.341\end{array}$} & \multicolumn{2}{|c|}{ Angle } \\
\hline Ca1-O1 & $2.3472(9)$ & & O1-Ca1-O4 & $87.42(3)$ \\
\hline $\mathrm{Ca} 1-\mathrm{O} 2$ & $2.4036(9)$ & 0.297 & O1-Ca1-O4 & 87.90(3) \\
\hline $\mathrm{Ca} 1-\mathrm{O} 2$ & $2.4260(9)$ & 0.281 & $\mathrm{O} 2-\mathrm{Ca} 1-\mathrm{O} 2$ & $85.60(2)$ \\
\hline Ca1-O3 & $2.5482(10)$ & 0.209 & $\mathrm{O} 2-\mathrm{Ca} 1-\mathrm{O} 3$ & $70.59(3)$ \\
\hline $\mathrm{Ca} 1-\mathrm{O} 3$ & $2.3220(9)$ & 0.363 & $\mathrm{O} 2-\mathrm{Ca} 1-\mathrm{O} 3$ & $148.13(3)$ \\
\hline Ca1-O4 & $2.3510(9)$ & 0.338 & O2-Ca1-O4 & $121.46(3)$ \\
\hline $\mathrm{Ca} 1-\mathrm{O} 4$ & $2.5115(9)$ & 0.228 & $\mathrm{O} 2-\mathrm{Ca} 1-\mathrm{O} 4$ & $149.91(3)$ \\
\hline$<\mathrm{Ca} 1-\mathrm{O}>$ & 2.416 & 2.057 & O3-Ca1-O1 & 176.17(3) \\
\hline \multirow[t]{2}{*}{$\mathrm{Ca} 1 \cdots \mathrm{O} 1{ }^{* *}$} & $3.413(1)$ & 0.025 & $\mathrm{O} 3-\mathrm{Ca} 1-\mathrm{O} 2$ & $74.15(3)$ \\
\hline & & & O3-Ca1-O2 & $89.75(3)$ \\
\hline $\mathrm{C} 1-\mathrm{O} 1$ & $1.2447(15)$ & & O3-Ca1-O3 & $84.58(3)$ \\
\hline $\mathrm{C} 1-\mathrm{O} 2$ & $1.2667(15)$ & & O3-Ca1-O4 & $91.74(3)$ \\
\hline C1-H1 & $0.952(19)$ & & O3-Ca1-O4 & $95.34(3)$ \\
\hline $\mathrm{C} 2-\mathrm{O} 3$ & $1.2518(16)$ & & O4-Ca1-O2 & $84.29(3)$ \\
\hline $\mathrm{C} 2-\mathrm{O} 4$ & $1.2512(17)$ & & $\mathrm{O} 4-\mathrm{Ca} 1-\mathrm{O} 2$ & $166.99(3)$ \\
\hline \multirow[t]{2}{*}{ C2-H2 } & $0.969(17)$ & & O4-Ca1-O3 & $51.39(3)$ \\
\hline & & & O4-Ca1-O3 & $121.75(3)$ \\
\hline \multicolumn{2}{|c|}{ Angle } & & $\mathrm{O} 4-\mathrm{Ca} 1-\mathrm{O} 4$ & $70.45(4)$ \\
\hline O1-Ca1-O2 & $108.28(3)$ & & $\mathrm{O} 1-\mathrm{C} 1-\mathrm{O} 2$ & $125.26(13)$ \\
\hline O1-Ca1-O2 & $87.51(3)$ & & $\mathrm{O} 3-\mathrm{C} 2-\mathrm{O} 4$ & $122.44(13)$ \\
\hline O1-Ca1-O3 & $91.98(3)$ & & & \\
\hline
\end{tabular}

* Bond-valence sums were calculated using [20]. ${ }^{* *}$ Contact is not included in the coordination sphere of Ca atom; see text for details. 


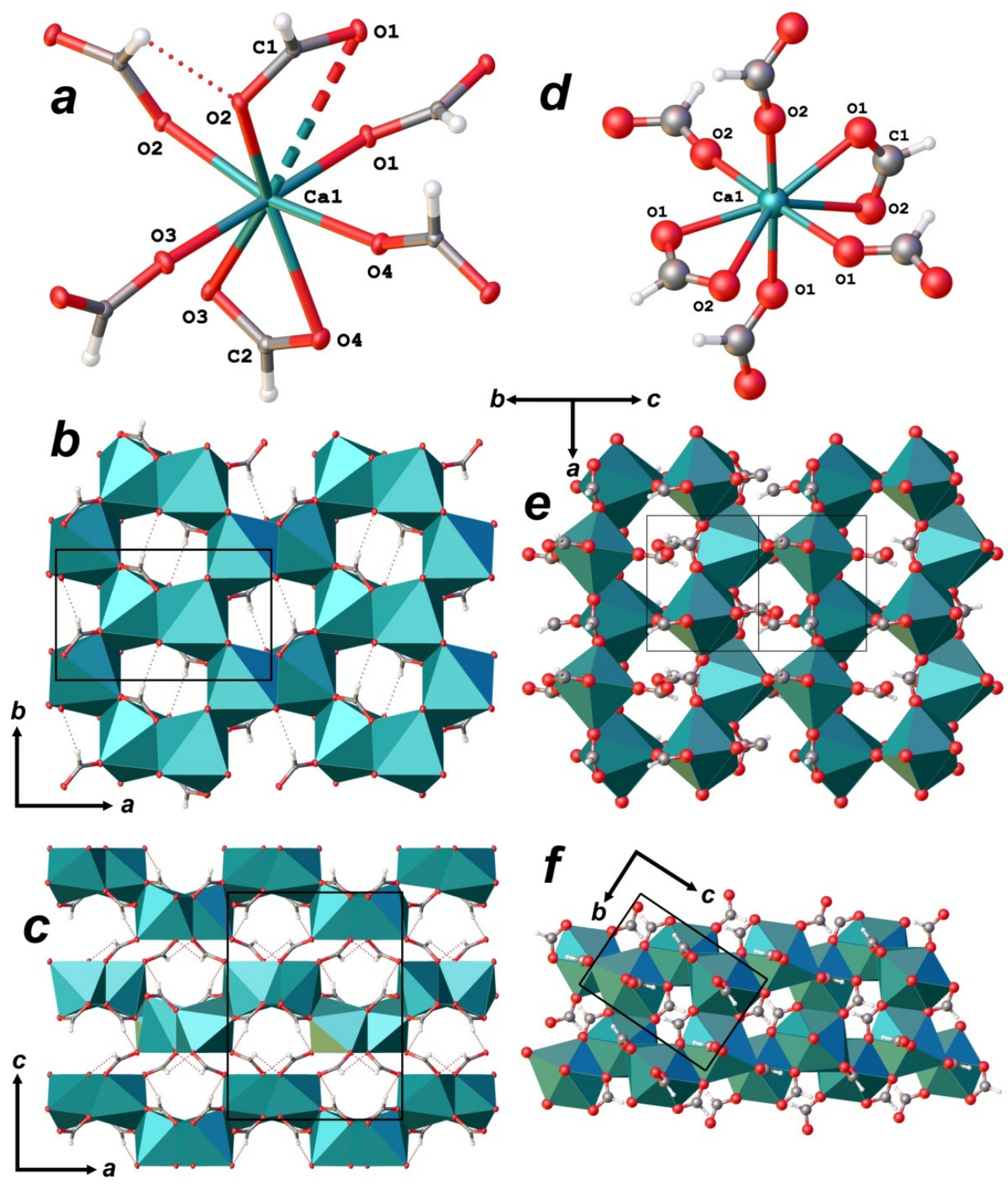

Figure 4. Coordination geometry of $\mathrm{Ca}$ atoms, dioctahedral-like layers, and their stacking in the structures of $\alpha-\mathrm{Ca}\left(\mathrm{HCO}_{2}\right)_{2}(\mathbf{a}-\mathbf{c})$ and formicaite $(\mathbf{d}-\mathbf{f})$. Legend: $\mathrm{Ca}$ atoms and polyhedra = cyan; $\mathrm{O}$ atoms $=$ red; $\mathrm{C}$ atoms $=$ grey $; \mathrm{H}$ atoms $=$ white; $\mathrm{H}$ bonds $=$ thin red dashed lines; $\mathrm{Ca} 1 \cdots \mathrm{O} 1$ contact $=$ stippled line; thermal ellipsoids $(\mathbf{a}-\mathbf{c})$ are shown at the 50\% probability level.

In contrast to $\alpha-\mathrm{Ca}(\mathrm{HCOO})_{2}$, in which all atoms occupy general sites, the crystal structure of the tetragonal $\beta$-modification (formicaite) contained one unique Ca atomoccupying special site on a 2-fold axis, and one unique formate anion, all atoms of which occupy general sites. The $\mathrm{Ca}$ atom is coordinated by eight $\mathrm{O}$ atoms that belong to two trans arranged chelating bidentate formate groups and four monodentate formate ligands. The coordination polyhedron of $\mathrm{Ca}$ atom in the structure of $\beta-\mathrm{Ca}(\mathrm{HCOO})_{2}$ can also be described as a distorted pentagonal bipyramid, in which four equatorial $\mathrm{O}$ atoms are arranged as in regular pentagonal bipyramid, and the fifth vertex is split into two sites that belong to the second chelating formate molecule and occur above and below the mean equatorial plane (Figure $4 \mathrm{~d}$ ). The average $\langle\mathrm{Ca}-\mathrm{O}\rangle$ distance in the structure of $\beta$ $\mathrm{Ca}(\mathrm{HCOO})_{2}$ was equal to $2.526 \AA$ and was larger than that for $\alpha-\mathrm{Ca}(\mathrm{HCOO})_{2}$, which was due to the 8-fold coordination and XRD data collection at room temperature [5]. On the other hand, the BVS parameters for Ca atoms in the structures of both $\alpha-(2.057$ v.u.) and $\beta$-modifications (2.044 v.u.) were comparable. In $\beta-\mathrm{Ca}(\mathrm{HCOO})_{2}$, the Ca-centered polyhedra shared edges with the adjacent complexes to form dioctahedral-like layers (Figure 4e) that 
were arranged parallel to (101) and equivalent planes perpendicular to the $4_{1}$-fold axis. Unlike the structure of $\alpha-\mathrm{Ca}(\mathrm{HCOO})_{2}$, these layers in $\beta-\mathrm{Ca}(\mathrm{HCOO})_{2}$ were interlinked with each other directly, without spaces, by sharing edges of Ca polyhedra (Figure $4 \mathrm{f}$ ).

The powder diffraction pattern fits very well with the calculated from the structural data of $\alpha-\mathrm{Ca}\left(\mathrm{HCO}_{2}\right)_{2}$ from the Alkali Lake reported herein (Table 5). A calculated pattern was obtained using atomic coordinates generated from structural refinement and unit cell parameters refined from the powder pattern: $a=10.215(3) ; b=6.2787(15) ; c=13.312(5) \AA$; $V=853.8(3) \AA^{3}$.

Table 5. Powder X-ray diffraction data $(d$ in $\AA)$ for $\alpha-\mathrm{Ca}\left(\mathrm{HCO}_{2}\right)_{2}$ from Alkali Lake.

\begin{tabular}{|c|c|c|c|c|c|c|c|c|c|}
\hline$d_{\text {meas }}$ & $I_{\text {meas }}$ & $I_{\text {calc }}$ & $d_{\text {calc }}$ & $h k l$ & $d_{\text {meas }}$ & $I_{\text {meas }}$ & $I_{\text {calc }}$ & $d_{\text {calc }}$ & $h k l$ \\
\hline 6.692 & 5 & 7 & 6.656 & 002 & & & 4 & 1.922 & 511 \\
\hline 5.596 & 100 & 100 & 5.577 & 102 & 1.916 & 11 & 13 & 1.917 & 231 \\
\hline 4.965 & 60 & 57 & 4.963 & 111 & 1.865 & 9 & 14 & 1.859 & 306 \\
\hline 3.952 & 2 & 3 & 3.962 & 210 & & & 3 & 1.812 & 026 \\
\hline 3.793 & 15 & 18 & 3.798 & 211 & 1.807 & 1 & 4 & 1.809 & 423 \\
\hline 3.426 & 20 & 18 & 3.415 & 113 & 1.791 & 5 & 7 & 1.784 & 126 \\
\hline 3.406 & 96 & 94 & 3.405 & 212 & & & 2 & 1.782 & 316 \\
\hline 3.058 & 21 & 21 & 3.056 & 021 & & & 3 & 1.775 & 233 \\
\hline 2.961 & 87 & 82 & 2.955 & 213 & 1.767 & 11 & 19 & 1.767 & 331 \\
\hline \multirow[t]{2}{*}{2.928} & 4 & 3 & 2.927 & 121 & & & 2 & 1.746 & 134 \\
\hline & & 3 & 2.920 & 311 & 1.722 & 9 & 6 & 1.722 & 332 \\
\hline \multirow[t]{2}{*}{2.839} & 23 & 7 & 2.839 & 022 & & & 11 & 1.714 & 217 \\
\hline & & 29 & 2.826 & 114 & 1.704 & 3 & 2 & 1.703 & 600 \\
\hline 2.739 & 15 & 18 & 2.736 & 122 & & & 5 & 1.702 & 424 \\
\hline \multirow[t]{2}{*}{2.674} & 3 & 4 & 2.675 & 220 & 1.678 & 5 & 6 & 1.675 & 406 \\
\hline & & 4 & 2.554 & 400 & & & 2 & 1.674 & 234 \\
\hline 2.546 & 4 & 2 & 2.548 & 214 & 1.655 & 1 & 4 & 1.658 & 522 \\
\hline 2.490 & 12 & 13 & 2.486 & 123 & & & 2 & 1.642 & 108 \\
\hline \multirow[t]{2}{*}{2.483} & 15 & 14 & 2.481 & 313 & 1.632 & 1 & 4 & 1.631 & 611 \\
\hline & & 12 & 2.383 & 115 & 1.627 & 4 & 2 & 1.627 & 027 \\
\hline 2.291 & 20 & 24 & 2.284 & 024 & & & 5 & 1.624 & 135 \\
\hline 2.272 & 1 & 3 & 2.274 & 321 & 1.598 & 3 & 4 & 1.595 & 612 \\
\hline 2.234 & 16 & 12 & 2.229 & 124 & 1.591 & 2 & 2 & 1.589 & 425 \\
\hline 2.229 & 19 & 20 & 2.225 & 314 & & & 3 & 1.589 & 118 \\
\hline \multirow[t]{2}{*}{2.218} & 4 & 2 & 2.219 & 006 & & & 2 & 1.582 & 208 \\
\hline & & 3 & 2.210 & 215 & & & 2 & 1.541 & 141 \\
\hline \multirow[t]{3}{*}{2.180} & 17 & 19 & 2.181 & 322 & 1.538 & 5 & 11 & 1.541 & 613 \\
\hline & & 3 & 2.168 & 106 & 1.511 & 2 & 4 & 1.511 & 142 \\
\hline & & 2 & 2.048 & 323 & 1.480 & 2 & 5 & 1.480 & 043 \\
\hline 2.026 & 11 & 2 & 2.027 & 131 & & & 2 & 1.478 & 426 \\
\hline 2.001 & 2 & 10 & 2.026 & 404 & & & 5 & 1.470 & 028 \\
\hline \multirow[t]{2}{*}{1.994} & 16 & 6 & 1.992 & 125 & 1.421 & 2 & 3 & 1.426 & 119 \\
\hline & & 22 & 1.989 & 315 & & & 3 & 1.420 & 044 \\
\hline \multirow[t]{2}{*}{1.978} & 13 & 19 & 1.981 & 420 & 1.409 & 1 & 6 & 1.413 & 711 \\
\hline & & 5 & 1.960 & 132 & 1.398 & 1 & 3 & 1.394 & 408 \\
\hline 1.948 & 8 & 12 & 1.953 & 502 & 1.358 & 2 & 4 & 1.357 & 237 \\
\hline 1.936 & 4 & 6 & 1.937 & 230 & & & 6 & 1.356 & 526 \\
\hline
\end{tabular}

\section{Discussion}

An interaction of biogenic and abiogenic systems in nature and in laboratory conditions quite often leads to the formation of new materials, in particular mineral or minerallike species. Oxalate minerals, which are formed when the metabolic products of bacteria, micromycetes and lichens interact with rocks and minerals [21-24], can be regarded as a striking example of such interactions. Oxalic acid is not the only known product of the living cycle; organic acids such as acetic, citric, formic, and etc. were also detected among the metabolites of microorganisms [23]. Thus, one could expect the crystallization of various organic acids salts. However, in nature, mainly oxalates are found in macroscopic 
amounts, which is due to their low solubility. Even though formic acid was found as a metabolite of a number of microorganisms [25], formation of biogenic formates, similar to oxalate mineralization, is unlikely, due to the higher solubility of its salts and the fast consumption of formate by bacterial consortiums. To date, there are no findings of formates formed as a result of interaction of microorganisms with rocks and minerals. In this regard, the processes occurring in Alkali Lake as a result of specific biogeochemistry features, associated, among other things, with the pollution of the lake, created unique conditions for inhibition of methanogenesis, which lead to exceptional biogenic crystallization of formic acid salts.

The unusual accumulation of formate as centimeter-sized calcium formate crystals is a remarkable phenomenon from the viewpoint of formate biogeochemistry. Formate is an important metabolic intermediate and electron carrier in syntropic bacterial consortiums of anaerobic acetogens and methanogens [26]. Formate is excreted as the end-product of fermentation of organic materials, mainly by the action of pyruvate-formate lyase during acetogenic and ethanolic fermentation in both prokaryotes and eukaryotic anaerobes [27-30]. In the sediments of haloalkaline lakes, the presence of acetogenic fermentative bacteria could lead to elevated formate and acetate, used by methylotrophic methanogens or rapidly consumed by aerobic heterotrophic bacteria. Considering that methanogenesis was possibly a predominant process in the anoxic sediments, we assumed that the formate/acetate generated by anaerobic fermentation of organic matter produced by photosynthetic and heterotrophic aerobes in the oxic zone, may be a source of one carbon unit for the metabolism of the consortium of methanogens and methanotrophs [31,32]. To confirm the biogenic origin of the formate in the $\mathrm{Ca}\left(\mathrm{HCO}_{2}\right)_{2}$ crystals collected at Alkali Lake, we measured the carbon isotope composition of calcium formate, and associated gaylussite and sodium carbonate in the sediments. The $\delta^{13} \mathrm{C}$ value observed in carbonates was $-0.6 \%$, consistent with the equilibration with atmospheric $\mathrm{CO}_{2}$ and weathering origin of carbonates [33], and with the values observed for dissolved inorganic carbon above the chemocline in soda lake waters [34]. Instead, the observed carbon isotope abundance in formate was $\delta^{13} \mathrm{C}=-26.5 \%$, consistent with the $\delta^{13} \mathrm{C}$ of organic carbon observed in soda lake sediments (about -20\% [34]).

The strong accumulation of formate which lead to the crystallization of $\mathrm{Ca}\left(\mathrm{HCO}_{2}\right)_{2}$ can be explained either on the basis of the lake microbiology or as a consequence of anthropogenic pollution. The solution of this problem is relevant regarding the environmental consequences and transformation of pollutants. The methanogens isolated in the subsurface sediments of Alkali Lake belong mainly to the order Methanosarcinales, which are not able to grow using formate as a substrate; a methanogen community with a limited capacity for formate consumption could have favored its accumulation in the sediments $[35,36]$. This circumstance, together with the relative low solubility of calcium formate and desiccation of lake shores, could lead to the unique conditions of formate crystallization in Alkali Lake. On the other hand, in 1969 to 1971, the area near Alkali Lake was used as a waste storage area, and in 1976, production waste containing chlorophenolic compounds were released into the lake [37,38]. The released pollutants included 5000 cubic meters (25,000 $200 \mathrm{~L}$ drums) of the 2,4-dichlorophenoxyacetic acid (2,4-D) manufacture byproducts, a tactic warfare defoliant used under the names "herbicide orange" and "Agent Orange" during the Vietnam war [39-41]. These compounds, as well as other organochlorines, are strong inhibitors of methanogenesis, leading to the accumulation of formate $[26,42]$. The significant entry of organic pollutants in the lake sediments could have contributed to the increase of anoxia and the production of formate by anaerobic fermentation, but we think that pollutants were not a significant primary carbon source for the formate; there were no direct metabolic routes to formate from these pollutants, and, furthermore, if the pollutants were the carbon source, we would expect a lower $\delta^{13} \mathrm{C}$ (formate), in the range from $-30 \%$ to $-40 \%$, consistent with the isotope abundances of synthetic pollutants [43]. Instead, the carbon isotope abundances were expected for biogenic organic matter in sediments of a soda lake. Hence, the inhibition of methanogenesis in the anoxic sediments, possibly 
induced by industrial pollutants, led to the increase of formate concentration. It is possible that this increase, together with the ease of formate salts to form macroscopic crystals and the calcium saturation of the lake water, led to the unique crystallization of Ca formate observed in Alkali Lake (Figure 5).
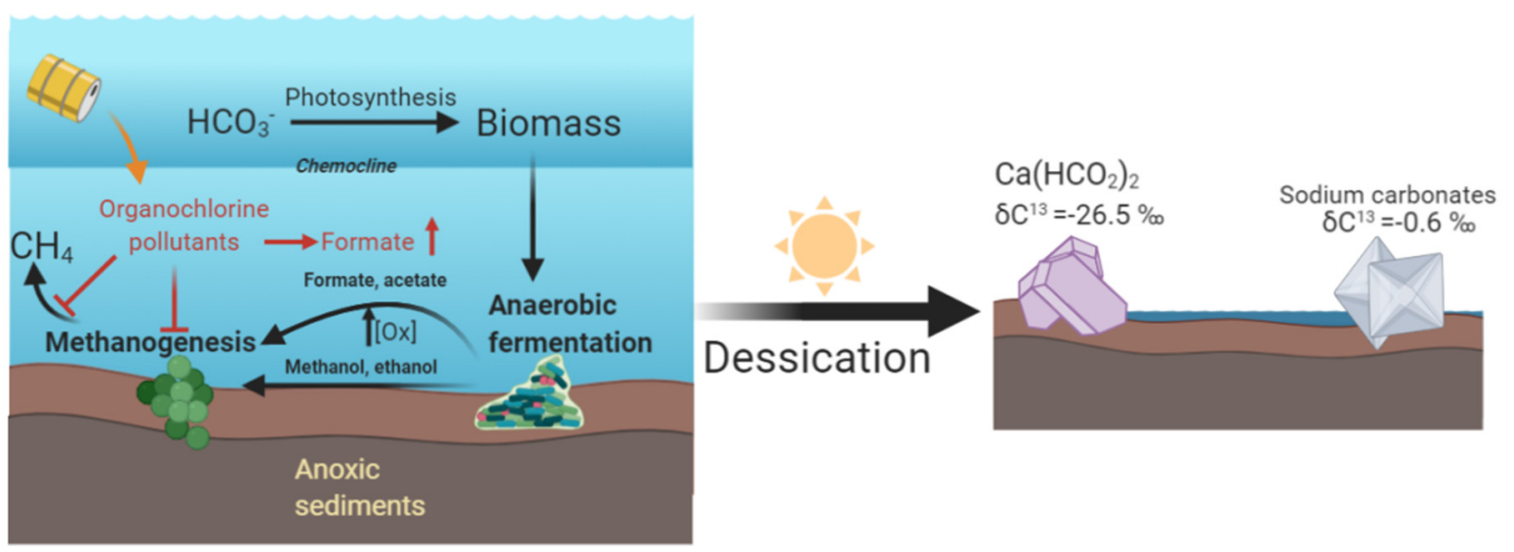

Figure 5. Schematic illustration of the proposed mechanism of biogenic $\alpha-\mathrm{Ca}\left(\mathrm{HCO}_{2}\right)_{2}$ crystal formation in the Alkali Lake sediments.

Orthorhombic $\alpha-\mathrm{Ca}\left(\mathrm{HCO}_{2}\right)_{2}$ was easily obtained by slow crystallization from aqueous solutions [11]. Thus, this polymorph was most stable at normal conditions. This assumption was in agreement with the occurrence of this phase in the lacustrine sediments, as well as with the fact that $\alpha-\mathrm{Ca}\left(\mathrm{HCO}_{2}\right)_{2}$ has the largest density $\left(\right.$ of $\left.2.040 \mathrm{~g} / \mathrm{cm}^{3}\right)$ among the $\mathrm{Ca}$ formate polymorphs. It was of interest that formicaite, a $\beta$-modification of $\mathrm{Ca}\left(\mathrm{HCO}_{2}\right)_{2}$ with the density of $1.991 \mathrm{~g} / \mathrm{cm}^{3}$, was described in nature prior [1] to $\alpha-\mathrm{Ca}\left(\mathrm{HCO}_{2}\right)_{2}$, which indicated that tetragonal $\beta$-calcium formate was also stable at ambient conditions, but there should be some stabilization mechanism for its occurrence. For instance, stabilization of low-density polymorphs by low amounts of enclathrated molecules is a usual phenomenon. Melanophlogite, a low-density cubic $\mathrm{SiO}_{2}$ modification stabilized by enclathrated $\mathrm{CH}_{4}$ and $\mathrm{N}_{2}$ molecules [44], and low-density modifications of 2,4,6,8,10,12-hexanitro-2,4,6,8,10,12hexaazaisowurtzitane stabilized by enclathrated $\mathrm{H}_{2} \mathrm{O}$ and $\mathrm{H}_{2} \mathrm{O}_{2}$ molecules $[45,46]$ can be given as an examples. Both formicaite discoveries (in both Novofrolovskoe and Solongo boron-rich skarn deposits) were confined to associations of boron minerals. Thus, one cannot exclude that trace amounts of any boron-bearing species may stabilize the lowdensity $\beta-\mathrm{Ca}\left(\mathrm{HCO}_{2}\right)_{2}$ structure.

Supplementary Materials: The following are available online at https:/ / www.mdpi.com/article/10 $.3390 / \min 11050448 / \mathrm{s} 1$ : Structural data (cif) file.

Author Contributions: Conceptualization, N.V.C., C.M.-S., I.V.P. and V.V.G.; methodology, N.V.C., C.M.-S., I.V.P. and V.V.G.; investigation, N.V.C., C.M.-S., V.V.G., A.R.I., M.F.V., D.A.K. and S.N.B.; writing —original draft preparation, N.V.C. and C.M.-S.; writing—review \& editing, I.V.P., A.R.I., V.V.G. and N.V.C.; visualization, N.V.C., C.M.-S. and A.R.I. All authors have read and agreed to the published version of the manuscript.

Funding: This work was performed in accordance with the state task, state registration no. AAAA19-119092390076-7 (mineralogical study and IR spectroscopy), and was partly supported by the Lomonosov Moscow State University Program of Development (Raman spectroscopy) and by the President of Russian Federation grant to leading scientific schools (grant NSh-2526.2020.5 to A.R.I. and V.V.G.).

Institutional Review Board Statement: Not Applicable.

Informed Consent Statement: Not Applicable.

Data Availability Statement: Not Applicable. 
Acknowledgments: The XRD studies were performed at the X-ray Diffraction Centre of the St. Petersburg State University. The isotopic study was performed in the Laboratory of Stable Isotopes at the Universidad Autónoma de Madrid. Thanks to Jordi Fabre, who kindly provided part of the samples used in this work. We are grateful to reviewers for their useful comments.

Conflicts of Interest: The authors declare no conflict of interest.

\section{References}

1. Chukanov, N.V.; Malinko, S.V.; Lisitsyn, A.E.; Dubinchuk, V.T.; Kuz'mina, O.V.; Zadov, A.E. Formicaite, $\left.\mathrm{Ca}_{(\mathrm{HCO}}\right)_{2}$, a new mineral. Zap. Vseross. Miner. Obs. (Proc. Russ. Miner. Soc.) 1999, 128, 43-48. (In Russian)

2. Chukanov, N.V.; Belakovskiy, D.I.; Malinko, S.V.; Organova, N.I. Dashkovaite, $\mathrm{Mg}\left(\mathrm{HCO}_{2}\right)_{2} \cdot 2 \mathrm{H}_{2} \mathrm{O}$, a new formate mineral. Zap. Vseross. Miner. Ova. (Proc. Russ. Miner. Soc.) 2000, 129, 49-53. (In Russian)

3. Comel, C.; Mentzen, B.F. Comparative study of the polymorphic species of strontium and calcium formates. I. Differential Thermal Analysis (DTA). J. Solid State Chem. 1974, 9, 210-213. [CrossRef]

4. Mentzen, B.F.; Comel, C. Comparative study of the polymorphic species of strontium and calcium formates. II. X-Ray diffraction. J. Solid State Chem. 1974, 9, 214-223. [CrossRef]

5. Matsui, M.; Watanabé, T.; Kamijo, N.; Lapp, R.L.; Jacobson, R.A. The structures of calcium formate $\beta$-Ca(HCOO) 2 and $\delta$ $\mathrm{Ca}(\mathrm{HCOO})_{2}$, and the tetragonal mixed crystals $\mathrm{Ca}(\mathrm{HCOO})_{2}-\mathrm{Sr}(\mathrm{HCOO})_{2}$. Acta Crystallogr. 1980, B36, 1081-1086. [CrossRef]

6. Nitta, I.; Osaki, K. Crystal structure of calcium formate. X-Sen Osaka Univ. 1948, 5, 37-42. [CrossRef]

7. Burger, N.; Fuess, H.; Mason, S.A. Neutron diffraction of $\alpha$-calcium formate at 100 and 296 K. Acta Crystallogr. 1977, B33, 1968-1970. [CrossRef]

8. Bargouth, M.O.; Will, G. Calcium formate $\mathrm{Ca}(\mathrm{HCOO})_{2}$ (neutron). Cryst. Struct. Commun. 1980, 9, 605-613.

9. Fuess, H.; Burger, N.; Bats, J.W. Deformationsdichteverteilung in Salzen komplexer Anionen I: X-N-Dichte in $\alpha$-Calciumformiat bei $100 \mathrm{~K}$ und $296 \mathrm{~K}$. Z. Kristallogr. 1981, 156, 219-232. [CrossRef]

10. Watanabé, T.; Matsui, M. A redetermination of the crystal structures of $\alpha$-calcium formate, $\alpha$-strontium formate and barium formate by X-ray analyses. Acta Crystallogr. 1978, B34, 2731-2736. [CrossRef]

11. Silaev, V.I.; Rakin, V.I.; Shanina, S.N.; Petrovskiy, V.A.; Shiryaeva, L.L. To mineralogy of the crystallic calcium formiate. Ural. Geol. Zhurnal (Ural Geol. J.) 2005, 46, 107-123. (In Russian)

12. WINXPOW; Stoe \& Cie: Darmstadt, Germany, 2004.

13. CrysAlisPro Software System, Version 1.171.40.50a; Rigaku Oxford Diffraction: Oxford, UK, 2019.

14. Sheldrick, G.M. SHELXT-Integrated space-group and crystal structure determination. Acta Cryst. 2015, A71, 3-8. [CrossRef]

15. Sheldrick, G.M. Crystal structure refinement with SHELXL. Acta Cryst. 2015, C71, 3-8. [CrossRef]

16. Dolomanov, O.V.; Bourhis, L.J.; Gildea, R.J.; Howard, J.A.K.; Puschmann, H. OLEX2: A complete structure solution, refinement and analysis program. J. Appl. Cryst. 2009, 42, 339-341. [CrossRef]

17. Ito, K.; Bernstein, H.J. The vibrational spectra of the formate, acetate, and oxalate ions. Can. J. Chem. 1956, 34, 170-178. [CrossRef]

18. Krishnan, R.S.; Ramanujam, P.S. Raman spectrum of calcium formate. J. Raman Spectrosc. 1973, 1, 533-538. [CrossRef]

19. Wang, S.; Kong, P.; Zhang, Z.; Sun, H.; Li, P.; Chen, R.; Gu, B.; Ungar, G.; Wu, X.; Cheng, L.; et al. Structure, morphology, and nonlinear optical properties of orthorhombic $\alpha-\mathrm{Ca}(\mathrm{HCOO})_{2}$ single crystals. Opt. Mater. Express 2018, 8, 2238-2245. [CrossRef]

20. Gagné, O.C.; Hawthorne, F.C. Comprehensive derivation of bond-valence parameters for ion pairs involving oxygen. Acta Cryst. 2015, B71, 561-578. [CrossRef]

21. Sazanova, K.V.; Vlasov, D.Y.; Osmolovskay, N.G.; Schiparev, S.M.; Rusakov, A.V. Significance and regulation of acids production by rock-inhabited fungi. In Biogenic-Abiogenic Interactions in Natural and Anthropogenic Systems; Frank-Kamenetskaya, O.V., Panova, E.G., Vlasov, D.Y., Eds.; Springer: Zug, Switzerland, 2016; pp. 379-392. [CrossRef]

22. Frank-Kamenetskaya, O.V.; Ivanyuk, G.Y.; Zelenskaya, M.S.; Izatulina, A.R.; Kalashnikov, A.O.; Vlasov, D.Y.; Polyanskaya, E.I. Calcium Oxalates in Lichens on Surface of Apatite-Nepheline Ore (Kola Peninsula, Russia). Minerals 2019, 9, 656. [CrossRef]

23. Vlasov, D.Y.; Frank-Kamenetskaya, O.V.; Zelenskaya, M.S.; Sazanova, K.V.; Rusakov, A.D.; Izatulina, A.R. The use of Aspergillus niger in modeling of modern mineral formation in lithobiotic systems. In Aspergillus niger: Pathogenicity, Cultivation and Uses; Baughan, E., Ed.; Nova Science Publishers: New York, NY, USA, 2020; pp. 1-123.

24. Frank-Kamenetskaya, O.V.; Zelenskaya, M.S.; Izatulina, A.R.; Gurzhiy, V.V.; Rusakov, A.V.; Vlasov, D.Y. Oxalate formation by Aspergillus niger on manganese ore minerals. Am. Miner.. (in press). [CrossRef]

25. Li, Z.; Bai, T.; Dai, L.; Wang, F.; Tao, J.; Meng, S.; Hu, Y.; Wang, S.; Hu, S. A study of organic acid production in contrasts between two phosphate solubilizing fungi: Penicillium oxalicum and Aspergillus niger. Sci. Rep. 2016, 6, 25313. [CrossRef] [PubMed]

26. Thiele, J.H.; Zeikus, J.G. Control of Interspecies Electron Flow during Anaerobic Digestion: Significance of Formate Transfer versus Hydrogen Transfer during Syntrophic Methanogenesis in Flocs. Appl. Environ. Microbiol. 1988, 54, 20-29. [CrossRef]

27. Crain, A.V.; Broderick, J.B. Pyruvate formate-lyase and its activation by pyruvate formate-lyase activating enzyme. J. Biol. Chem. 2014, 289, 5723-5729. [CrossRef] [PubMed]

28. Muller, M.; Mentel, M.; van Hellemond, J.J.; Henze, K.; Woehle, C.; Gould, S.B.; Yu, R.-Y.; van der Giezen, M.; Tielens, A.G.M.; Martin, W.F. Biochemistry and Evolution of Anaerobic Energy Metabolism in Eukaryotes. Microbiol. Mol. Biol. Rev. 2012, 76, 444-495. [CrossRef] 
29. Atteia, A.; Van Lis, R.; Tielens, A.G.M.; Martin, W.F. Anaerobic energy metabolism in unicellular photosynthetic eukaryotes. Biochim. Biophys. Acta Bioenerg. 2013, 1827, 210-223. [CrossRef]

30. Wolfe, A.J. The Acetate Switch. Microbiol. Mol. Biol. Rev. 2005, 69, 12-50. [CrossRef] [PubMed]

31. Antony, C.P.; Kumaresan, D.; Hunger, S.; Drake, H.L.; Murrell, J.C.; Shouche, Y.S. Microbiology of Lonar Lake and other soda lakes. ISME J. 2013, 7, 468-476. [CrossRef]

32. Dong, H.; Zhang, G.; Jiang, H.; Yu, B.; Chapman, L.R.; Lucas, C.R.; Fields, M.W. Microbial diversity in sediments of saline Qinghai Lake, China: Linking geochemical controls to microbial ecology. Microb. Ecol. 2006, 51, 65-82. [CrossRef]

33. Eugster, H.P.; Hardie, L.A. Saline Lakes. In Lakes; Lerman, A., Ed.; Springer: New York, NY, USA, 1978; pp. 237-293. [CrossRef]

34. Oremland, R.S.; Des Marais, D.J. Distribution, abundance and carbon isotopic composition of gaseous hydrocarbons in Big Soda Lake, Nevada: An alkaline, meromictic lake. Geochim. Cosmochim. Acta 1983, 47, 2107-2114. [CrossRef]

35. Kendall, M.M.; Boone, D.R. The Order Methanosarcinales. In The Prokaryotes; Dworkin, M., Falkow, S., Rosenberg, E., Schleifer, K.H., Stackebrandt, E., Eds.; Springer: New York, NY, USA, 2006; pp. 244-256. [CrossRef]

36. Liu, Y.; Boone, D.R.; Choy, C. Methanohalophilus oregonense sp. nov. a methylotrophic methanogen from an alkaline, saline aquifer. Int. J. Syst. Bacteriol. 1990, 40, 111-116. [CrossRef]

37. Pankow, J.F.; Isabelle, L.M.; Barofsky, D.F. The identification of chlorophenoxyphenols in soil and water samples by solvent extraction and field desorption mass spectrometry. Anal. Chim. Acta 1981, 124, 357-364. [CrossRef]

38. Maltseva, O.; McGowan, C.; Fulthorpet, R.; Oriel, P. Degradation of 2,4-dichlorophenoxyacetic acid by haloalkaliphilic bacteria. Microbiology 1996, 142, 1115-1122. [CrossRef]

39. Young, A.L.; Calcagni, J.A.; Thalken, C.E.; Tremblay, J.W. The toxicology, environmental fate, and human risk of herbicide orange and its associated dioxin. In U.S. Air Force OEHL Technical Report; United States Air Force Occupational and Environmental Health Laboratory, Aerospace Medical Division (AFSC), Brooks Air Force Base: San Antonio, TX, USA, 1978; TR-78-92.

40. Johnson, R.L.; Brillante, S.M.; Isabella, L.M.; Houck, J.E.; Pankow, J.F. Migration of Chlorophenolic Compounds at the Chemical Waste Disposal Site at Alkali Lake, Oregon-1. Site Description and Ground-Water Flow. Groundwater 1984, 22, 593-601. [CrossRef]

41. Johnson, R.L.; Brillante, S.M.; Isabella, L.M.; Houck, J.E.; Pankow, J.F. Migration of Chlorophenolic Compounds at the Chemical Waste Disposal Site at Alkali Lake, Oregon-2. Contaminant Distributions, Transport, and Retardation. Groundwater 1985, 23, 652-666. [CrossRef]

42. Puyol, D.; Sanz, J.L.; Rodriguez, J.J.; Mohedano, A.F. Inhibition of methanogenesis by chlorophenols: A kinetic approach. New Biotechnol. 2012, 30, 51-61. [CrossRef] [PubMed]

43. Aeppli, C.; Tysklind, M.; Holmstrand, H.; Gustafsson, O. Use of $\mathrm{Cl}$ and $\mathrm{C}$ isotopic fractionation to identify degradation and sources of polychlorinated phenols. Environ. Sci. Technol. 2013, 47, 790-797. [CrossRef]

44. Gies, H. Studies on clathrasils. III. Crystal structure of melanophlogite, a natural clathrate compound of silica. Z. Kristallogr. 1983, 164, 247-257. [CrossRef]

45. Golovina, N.I.; Raevskiy, A.V.; Chukanov, N.V.; Korsunskiy, B.L.; Shilov, G.V.; Atovmyan, L.O.; Aldoshin, S.M. Density of crystals of 2,4,6,8,10,12-hexanitro-2,4,6,8,10,12-hexaazaisowurtzitane, a potential ligand. Ross. Khimicheskiy Zhurnal (Russian Chem. J.) 2004, 48, 41-48. (In Russian)

46. Bennion, J.C.; Chowdhury, N.; Kampf, J.W.; Matzger, A.J. Hydrogen peroxide solvates of 2,4,6,8,10,12-hexanitro-2,4,6,8,10,12hexaazaisowurtzitane. Angew. Chem. 2016, 128, 13312-13315. [CrossRef] 